Article

\title{
Novel Antimicrobial Titanium Dioxide Nanotubes Obtained through a Combination of Atomic Layer Deposition and Electrospinning Technologies
}

\author{
Carol López de Dicastillo ${ }^{1,2, *}$ (D) Cristian Patiño ${ }^{1,2}$, María Jose Galotto ${ }^{1,2}$, Juan Luis Palma ${ }^{2,3}$, \\ Daniela Alburquenque ${ }^{2,4}$ and Juan Escrig ${ }^{2,4}$ (1) \\ 1 Food Packaging Laboratory (Laben-Chile), Department of Science and Food Technology, Faculty of \\ Technology, Universidad de Santiago de Chile (USACH), Obispo Umaña 050, 9170201 Santiago, Chile; \\ cristian.patino@usach.cl (C.P.); maria.galotto@usach.cl (M.J.G.) \\ 2 Center for the Development of Nanoscience and Nanotechnology (CEDENNA), 9170124 Santiago, Chile; \\ juanluispalma@gmail.com (J.L.P.); daniela.alburquenquem@usach.cl (D.A.); juan.escrig@usach.cl (J.E.) \\ 3 Department of Basic Sciences, Engineering Faculty, CIDES, Universidad Central de Chile, Santa Isabel 1186, \\ 8330601 Santiago, Chile \\ 4 Department of Physics, Universidad de Santiago de Chile (USACH), Av. Ecuador 3493, 9170124 Santiago, Chile \\ * Correspondence: analopez.dediscastillo@usach.cl
}

Received: 23 December 2017; Accepted: 13 February 2018; Published: 24 February 2018

\begin{abstract}
The search for new antimicrobial substances has increased in recent years. Antimicrobial nanostructures are one of the most promising alternatives. In this work, titanium dioxide nanotubes were obtained by an atomic layer deposition (ALD) process over electrospun polyvinyl alcohol nanofibers (PVN) at different temperatures with the purpose of obtaining antimicrobial nanostructures with a high specific area. Electrospinning and ALD parameters were studied in order to obtain PVN with smallest diameter and highest deposition rate, respectively. Chamber temperature was a key factor during ALD process and an appropriate titanium dioxide deposition performance was achieved at $200{ }^{\circ} \mathrm{C}$. Subsequently, thermal and morphological analysis by SEM and TEM microscopies revealed hollow nanotubes were obtained after calcination process at $600{ }^{\circ} \mathrm{C}$. This temperature allowed complete polymer removal and influenced the resulting anatase crystallographic structure of titanium dioxide that positively affected their antimicrobial activities. X-ray analysis confirmed the change of titanium dioxide crystallographic structure from amorphous phase of deposited PVN to anatase crystalline structure of nanotubes. These new nanostructures with very large surface areas resulted in interesting antimicrobial properties against Gram-positive and Gram-negative bacteria. Titanium dioxide nanotubes presented the highest activity against Escherichia coli with $5 \log$ cycles reduction at $200 \mu \mathrm{g} / \mathrm{mL}$ concentration.
\end{abstract}

Keywords: nanotechnology; atomic layer deposition; electrospinning; titanium dioxide nanotubes; antimicrobial

\section{Introduction}

In the recent past, foodborne illnesses and nosocomial infections occurred during hospitalization have been identified as two major problems that have been producing many economic and human losses. Nosocomial infections represent around 1.4 million infections every year [1,2]. In addition, several studies have evidenced that the widespread use of antibiotics has led to bacteria resistance to nearly all antibiotics. These problems have induced the need and interest of the scientific society in the search for powerful antimicrobial substances. Recently, nanotechnology is considered a useful technology in treating bacterial infections since the mode of action of nanoparticles is in direct contact with the bacteria cell wall without the need to penetrate them, being less prone to promote resistance in 
bacteria than antibiotics. The development of novel and efficient nanotechnological-based antimicrobial agents is among one of the priority areas in biomedical research [3-5]. Several nanoparticles (NPs) have demonstrated broad-spectrum antibacterial properties against both Gram-positive and Gram-negative bacteria, mainly silver NPs, zinc oxide NPs, carbon nanotubes and iron oxide NPs [6-8]. The control of NPs morphology and structure is an important factor because antimicrobial performance is highly influenced by the morphology, shape and size of the particles $[9,10]$. The increase in surface area or the design of an appropriate sized and shaped nanoparticle with desirable surface properties can lead to an improvement of bactericidal activity. Some works have already evidenced that silver NPs interacts with bacteria, fungi and viruses in a shape-dependent manner [11-15]. Consequently, the development of new nanostructures with different morphologies has recently attracted wide attention. In this work, electrospinning (EP) and atomic layer deposition (ALD) technologies were combined with the objective to develop novel antimicrobial nanotubes with well-defined nanoscale walls composed of titanium dioxide.

EP is regarded as one of the most widespread techniques offering rapid, inexpensive, simple, effective and relatively large-scale fabrication for fibrous structures. An electrical potential is applied between a droplet of a polymer solution held at the end of a capillary tube and grounded target and when the applied electric field overcomes the surface tension of the droplet, a charged jet of polymer solution is ejected and is controlled by the electric field [16,17]. On the other hand, ALD has been recognized as a key technology for the surface modification and the fabrication of nanostructures materials because it is the only applicable technique for the deposition of conformal and homogenous thin films [18]. In addition, this technique allows to deposit thin films in structures with complex geometries allowing to synthesize high aspect ratio nanostructures without shadowing effects [19]. ALD is based on a reaction between precursor materials which are separated into successive surface reactions separated by a purge step to remove the unreacted precursors and the by-product. The deposition of metal oxides involves the reaction between a metal complex (e.g., metal halide, metal alkoxide, etc.) and an oxygen source (water, ozone or oxygen peroxide). Under hydrolytic conditions, the formation of M-O-M (metal-oxo dimers) bonds is separated into the two successive reactions: (i) a hydrolysis step during the water pulse forming -OH groups and metal-oxo bonds and (ii) a condensation step in which the resulting hydroxyl groups react with the metal oxide precursors supplied by the next pulse.

Other works have already reported this combination of techniques as an attractive strategy to obtain new nanostructures with photonic, electronic, catalytic, nanofluidic and drug delivery applications [20-22]. Different metal oxide nanotubes have been developed using different methodologies, precursors and fibers. Specifically, titanium dioxide nanotubes have been obtained using ALD and EP techniques but these works were mainly focused on their characterization [23-25]. However, no development has been carried out with antimicrobial purposes.

On the other hand, titanium dioxide $\left(\mathrm{TiO}_{2}\right)$ is a thermally stable and biocompatible chemical compound with high photocatalytic activity and has presented good results against bacterial contamination $[26,27]$. $\mathrm{TiO}_{2}$ has also become the preferred photocatalyst for a variety of reasons, which include its low cost, chemical stability, non-toxicity and effectiveness under near-ultraviolet light (300-400 nm). It is one of the most applied nanomaterials and is widely used as additive in food and non-food applications [28-30]. Other $\mathrm{TiO}_{2}$ nanostructures have been already developed with antimicrobial goals. $\mathrm{TiO}_{2}$ nanotubes obtained through a chlorine-based electrochemical anodization method when exposed to UV light during $24 \mathrm{~h}$ presented approximately one and three log reductions against $E$. coli and $S$. aureus, respectively, with starting bacterial working solutions at $10^{3} \mathrm{cfu} / \mathrm{mL}$. Recently, Jian et al. have developed $\mathrm{TiO}_{2}$ and silver loaded- $\mathrm{TiO}_{2}$ antibacterial agents through sol-assay method with minimum inhibition concentration values around $1.6 \mathrm{mg} / \mathrm{mL}[31,32]$. 


\section{Experimental Section}

\subsection{Materials}

\subsubsection{Polymers, Chemicals and Microorganisms}

Gohsenol type AH-17 polyvinyl alcohol (PV) (saponification degree 97-98.5\% and viscosity 25-30 mPa.s) was obtained from The Nippon Synthetic Chemical Co. (Osaka, Japan). Tetrakis (dimethylamide) titanium (TDMAT) (99.99\% trace metals basis) and titanium dioxide nanoparticles $\left(\mathrm{TiO}_{2}\right.$ NPs, $21 \mathrm{~nm}$ particle size) were obtained from Sigma Aldrich (Santiago, Chile).

Escherichia coli ATCC 25922, Listeria innocua ATCC 33090 and Staphylococcus aureus ATCC 25923 were chosen as Gram-negative and Gram-positive bacteria models. Bacterial strains were obtained from Biotechnology and Applied Microbiology Laboratory (LAMAP) (Santiago, Chile) and stored in glycerol $30 \%$ at $-80{ }^{\circ} \mathrm{C}$ until needed. For experimental use, the stock cultures were maintained in tryptone soy agar slants at $4{ }^{\circ} \mathrm{C}$ and transferred monthly. Prior to each experiment, a loopful of each strain was transferred to $5 \mathrm{~mL}$ of tryptone soy agar and incubated at $37^{\circ} \mathrm{C}$ for $16 \mathrm{~h}$ to obtain fresh early-stationary phase cells.

UVA lamp: 15W Philips UV-A (model Actinic BL TL TL-D 15W/10 1SL/25) (Amsterdam, The Netherland) light bulb was located $25 \mathrm{~cm}$ above the samples.

\subsubsection{Electrospun PV Nanofibers}

Poly (vinyl alcohol) nanofibers were obtained with a polymeric solution at $8 \%(w / w)$ using an electrospinning system (Spraybase ${ }^{\circledR}$ power Supply Unit, Maynooth, Ireland). $1.6 \mathrm{~g}$ poly (vinyl alcohol) (PV) was added to $20 \mathrm{~mL}$ of distilled water and stirred at $90{ }^{\circ} \mathrm{C}$ until polymer was dissolved. Solution was transferred to $5 \mathrm{~mL}$ plastic syringes and connected through a PTFE tube to a 16-gauge blunt (1.6 mm diameter) stainless steel needle charged by a high voltage power supply with a range of 0-20 kV, using $1.5 \mathrm{~mL} / \mathrm{h}$ as flow rate and $10 \mathrm{~cm}$ was the distance between the needle and the collector. Electrospun PV nanofibers were named "PVN." The parameters of electrospinning system, such as distance (height between tip of the needle and collector plate), diameter of needle and flow rate, were previously studied in order to determine their effect on the nanofiber diameter (Supplementary Information, Section S1.1).

\subsubsection{Atomic Layer Deposition Process (ALD)}

Coated electrospun PV nanofibers were obtained through the deposition of thin $\mathrm{TiO}_{2}$ layers using a Savannah S100 ALD equipment from Ultratech (San Jose, CA, USA) at different temperatures and purge times. During this process, the precursors Tetrakis (dimethylamide) titanium (TDMAT) and ultra-pure water were used as Ti and oxide sources, respectively. During cycling, the TDMAT and $\mathrm{H}_{2} \mathrm{O}$ were alternately introduced into the ALD chamber with pulse time of 0.1 and $0.015 \mathrm{~s}$, respectively. $\mathrm{N}_{2}$ was used as a carrier gas at a flow rate of $20 \mathrm{sccm}$. The temperatures of TDMAT and $\mathrm{H}_{2} \mathrm{O}$ were set to $75^{\circ} \mathrm{C}$ and room temperature, respectively. Three different temperatures in the ALD chamber were applied in order to study the influence of temperature in the process: (a) 500 cycles at $150{ }^{\circ} \mathrm{C}$ with a purge time of $20 \mathrm{~s}$; (b) 500 cycles at $200{ }^{\circ} \mathrm{C}$ with a purge time of $10 \mathrm{~s}$; and (c) $250 / 250$ cycles at $150 / 250{ }^{\circ} \mathrm{C}$ with a purge time of $20 / 5 \mathrm{~s}$ and coated PV nanofibers obtained for each temperature condition were named PVN_150, PVN_200 and PVN_150/250, respectively. Since inert gas purge time following the $\mathrm{H}_{2} \mathrm{O}$ pulse is a critical parameter to obtain a linear growth regime [33], purge time used for every temperature were according to the provider's recipe Cambridge NanoTech (Supplementary Information, Section S1.2).

\subsubsection{Polymer Template Removal}

Two methodologies were carried out to remove PV polymeric nanofiber in order to obtain hollow titanium dioxide nanotubes (TDN): Method (A) by washing: based on the hydrosoluble nature of PV 
polymer. Deposited samples were sonicated into water, previously warmed at $90{ }^{\circ} \mathrm{C}$, during $30 \mathrm{~min}$. Washing water was removed and a second washing was done under a vigorous stirring at $90^{\circ} \mathrm{C}$ during $3 \mathrm{~h}$ (sample TDN_A); and Method (B) by heating: based on polymeric thermal decomposition. Two temperatures were studied in order to observe the effect of temperature on polymer removal and $\mathrm{TiO}_{2}$ crystallization state. Coated nanofibers were thermal treated at $400{ }^{\circ} \mathrm{C}$ (sample TDN_B400) and $600{ }^{\circ} \mathrm{C}$ (sample TDN_B600), both during $2 \mathrm{~h}$.

\subsection{Characterization of Nanostructures: Nanofibers and Nanotubes}

\subsubsection{Electron Microscopy (SEM and TEM)}

The morphologies of PVN before and after ALD process and $\mathrm{TiO}_{2}$ nanotubes (TDN) obtained after the polymer template removal were studied by scanning electron microscopy (Zeiss EVO MA10 SEM, Oberkochen, Germany) at $20 \mathrm{kV}$ and transmission electron microscopy (Hitachi HT7700 high resolution TEM, Chiyoda, Tokyo, Japan) at $100 \mathrm{kV}$. Nanostructures images were recorded at different magnifications.

\subsubsection{X-ray Diffraction (XRD)}

XRD patterns were measured using a Siemens Diffractometer D5000 (30 mA and $40 \mathrm{kV}$ ) (Munich, Germany) using $\mathrm{CuKa}(\lambda=1.54 \AA)$ radiation at room temperature. All scans were performed in a $2 \theta$ range $2-80^{\circ}$ at $0.02^{\circ} / \mathrm{s}$. Debye-Scherrer's equation was used to calculate the crystallites size (nm).

\subsubsection{Fourier Transform Infrared Spectroscopy (FTIR)}

The presence of specific functional groups in the developed materials was analyzed by spectrometer equipment Bruker Alpha (Ettlingen, Karlsruhe, Germany) with accessory to make transmission spectra. Pellets with sample and potassium bromide $(\mathrm{KBr})$ were prepared by pressure and the spectra were obtained in a range from 4000 to $400 \mathrm{~cm}^{-1}$, with a resolution of $2 \mathrm{~cm}^{-1}$ and 64 scans.

\subsubsection{Thermal Properties}

Thermogravimetric analyses (TGA) were carried out using a Mettler Toledo Gas Controller GC20 Stare System TGA/DCS (Schwerzenbach, Switzerland). Samples (ca. $7 \mathrm{mg}$ ) were heated from 20 to $800{ }^{\circ} \mathrm{C}$ at $10{ }^{\circ} \mathrm{C} \mathrm{min}{ }^{-1}$ under nitrogen atmosphere (flow rate $50 \mathrm{~mL} \mathrm{~min}^{-1}$ ). PV polymer was also analyzed in order to study the effect of electrospinning process on polymer degradation.

\subsection{Antimicrobial Activity of $\mathrm{TiO}_{2}$ Hollow Nanotubes}

The antimicrobial activity of titanium dioxide nanotubes (TDN) developed in this work was tested under dynamic contact conditions against Listeria innocua and Staphylococcus aureus, as Gram-positive bacteria and Escherichia coli, as Gram-negative bacteria, following the International Normative ASTM E2149-10 with some modifications. TDN solutions at 100, 150, 200 and $400 \mu \mathrm{g} / \mathrm{mL}$ were made up in sterile buffer to study the antimicrobial activity. Commercial $\mathrm{TiO}_{2} \mathrm{NPs}$ were also analyzed in order to compare antimicrobial activities. Cell cultures of each microorganism in stationary phase measured at $600 \mathrm{~nm}$ were diluted in TSB and incubated at $37^{\circ} \mathrm{C}$ until reach the exponential phase corresponding with a bacterial concentration of $10^{8} \mathrm{CFU} / \mathrm{mL}$. Triple $1 / 10$ dilution was done, obtaining a final concentration of $10^{5} \mathrm{CFU} / \mathrm{mL}$ bacteria. Compounds were put in contact with bacterial solution and irradiated for $3 \mathrm{~h}$ using UVA lamp. Immediately after this irradiation period, $10 \mu \mathrm{L}$ of every experimental solution was grown in a Petri dish at $37^{\circ} \mathrm{C}$ by $24 \mathrm{~h}$. Bacterial solutions with and without UVA irradiation were used as controls. Antimicrobial activity was expressed as log cycles reduction through Equation (1):

$$
\log (\text { cycles }) \text { Reduction }=\log _{10}(\text { control })-\log _{10}(\text { experimental solution })
$$




\subsection{Statistical Analysis}

An analysis of variance (ANOVA) of microbiological studies was carried out. Fisher test $(\alpha=0.05)$ was used to calculate the minimum significant difference among samples. All calculations were carried out with XLSTAT Pro software 2015 (Addinsoft, Paris, France).

\section{Results and Discussion}

\subsection{Morphological Results of Nanofibers and Nanotubes}

As Figure 1a,e show, electrospun PVN were successfully obtained and presented a diameter average of $164.5 \pm 24.7 \mathrm{~nm}$ and exhibited smooth surfaces. These fibers were then coated with $\mathrm{TiO}_{2}$ by using ALD at different temperatures and as Figure $1 \mathrm{~b}-\mathrm{d}$ show, resulting samples "PVN_150, PVN_200 and PVN_150/250" presented different colors. Additionally, SEM images (Figure 1e-h) demonstrated that the mold structure of the PV nanofibers was maintained and deposited nanofibers were uniform and homogeneous. The sample deposited at $150^{\circ} \mathrm{C}$ presented a beige color and the third sample, deposited at $150{ }^{\circ} \mathrm{C}$ followed by $250^{\circ} \mathrm{C}$, showed a yellowish color. Interestingly, the sample acquired a bluish hue when deposition occurred at $200{ }^{\circ} \mathrm{C}$. The difference in coloration may be related to the optical interference owned to the number of cycles which can be occurred due to the superposition of the different layers of the deposited material [34]. In contrast, these results showed that not only the variation in the deposition cycles produced different colors but also a change in chamber's temperature caused different tonalities.
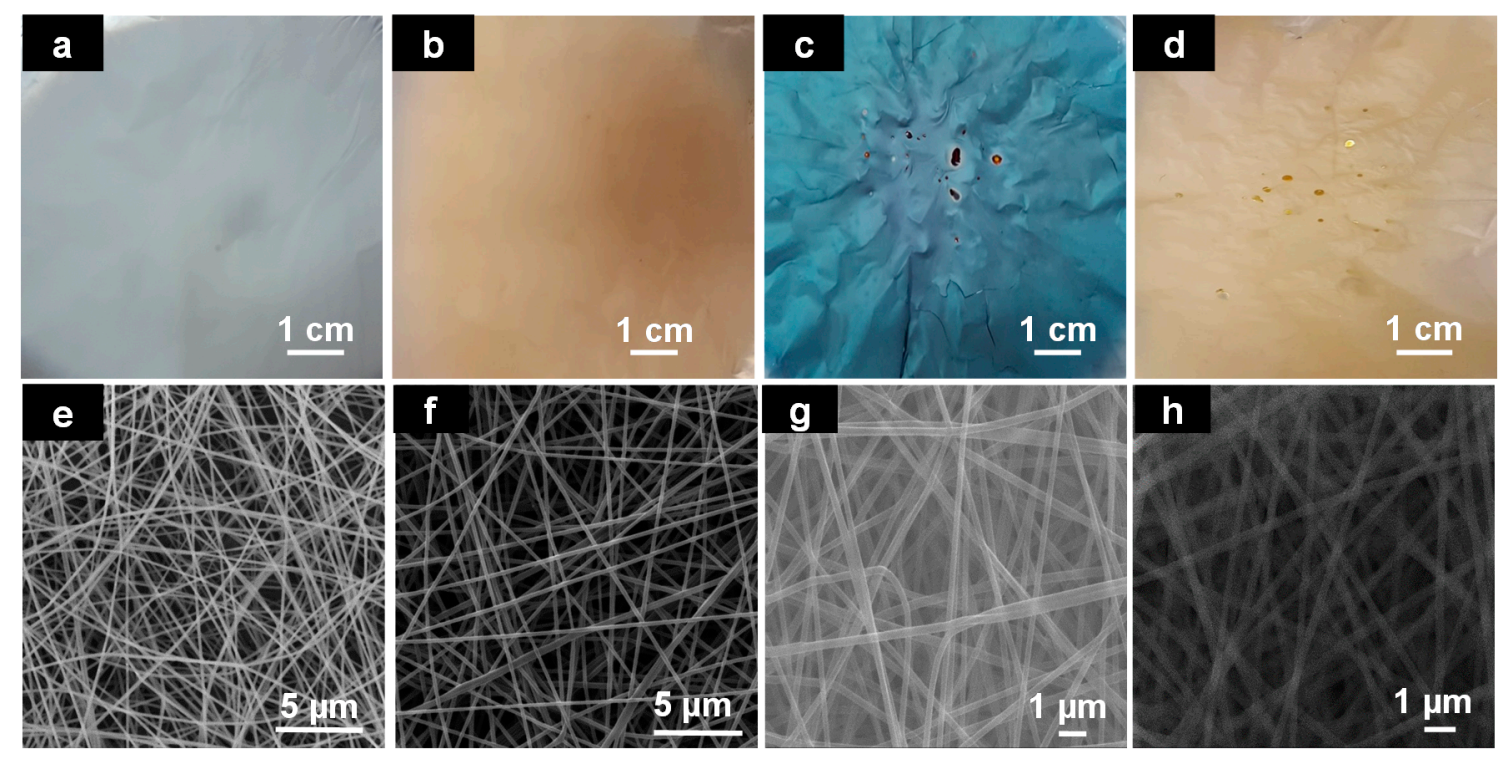

Figure 1. Photographs of electrospun fibers (PVN) (a) and deposited samples with $\mathrm{TiO}_{2}$ at different temperatures: (b) PVN_150, (c) PVN_200; (d) PVN_150/250; and SEM images of: (e) PVN, (f) PVN_150, (g) PVN_200, (h) PVN_150/250.

Subsequently, sample that presented highest deposition rate (PVN_200, according to thermal analysis in Section 3.2) suffered polymeric removal processes which were carried out with the purpose to obtain titanium dioxide nanotubes to enhance specific surface area of nanostructures. Figure 2 shows the color and the morphologies of titanium dioxides nanotubes (TDN) obtained using different methodologies aimed to remove PVN. In all cases, SEM and TEM images revealed that $\mathrm{TiO}_{2}$ deposition protected the morphology from removal processes and nanofibers served as an efficient "template" in the synthesis of titanium dioxide nanotubes. 

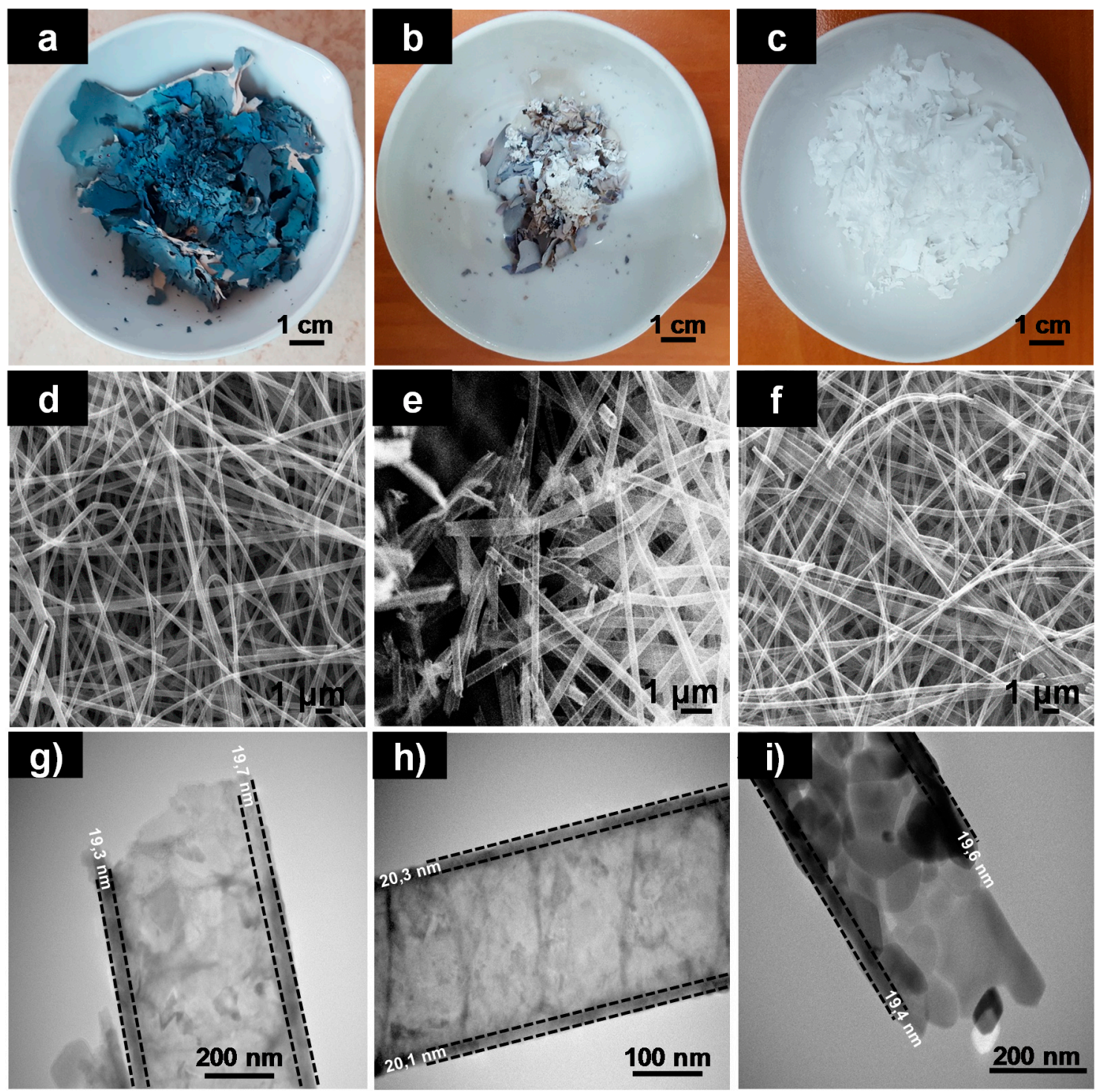

Figure 2. Photographs, SEM and TEM images of samples after removal processes. Photographs of: (a) TDN_A; (b) TDN_B400; (c) TDN_B600; SEM images of: (d) TDN_A; (e) TDN_B400; (f) TDN_B600; and TEM images of: (g) TDN_A; (h) TDN_B400 and (i) TDN_B600.

The polymer removal process by washing maintained the initial color (sample TDN_A shown in Figure 2a). Unexpectedly, when the sample was heated at $400{ }^{\circ} \mathrm{C}$, sample TDN_B400, the color of the nanotubes started to change from blue (Figure 1c) to white (Figure $2 b$ ), obtaining the total change to white at $600{ }^{\circ} \mathrm{C}$ (Figure 2c), sample TDN_B600. Certainly, this change of color was associated to $\mathrm{TiO}_{2}$ crystalline changes from amorphous phase to anatase crystalline structure (explained in next Section 3.4). Regarding to the thickness of $\mathrm{TiO}_{2}$ deposition, as Figure $2 \mathrm{~g}-\mathrm{i}$ shows, samples obtained after different polymer removal processes presented similar values. The results obtained after the measurement of 50 nanotubes were: $(19.3 \pm 2.7) \mathrm{nm},(20.1 \pm 2.4) \mathrm{nm}$ and $(19.4 \pm 2.6) \mathrm{nm}$ for TDN_A, TDN_B400 and TDN_B600, respectively. $\mathrm{TiO}_{2}$ thickness did not present significant differences between samples, showing that deposition occurred at $200{ }^{\circ} \mathrm{C}$ exhibited high uniformity. Moreover, at this chamber temperature, highest ALD efficiency was achieved since Growth per Cycle (GPC) was approximately 0.04 Angstroms/cycle (in agreement with provider's recipe).

On the other hand, nanotube diameters of samples with remaining PVN presented higher values than samples that suffered thermal decomposition at $600^{\circ} \mathrm{C}$. Probably, PVN suffered some swelling 
process due to the hydrophilic nature of this polymer and the presence of water as oxidant precursor during $\mathrm{TiO}_{2}$ ALD. And lately, nanotubes suffered some shrinking after thermal decomposition process, This fact was more accentuated at $600{ }^{\circ} \mathrm{C}$ [35].

In addition, SEM and TEM images of washed and thermal treated at $400{ }^{\circ} \mathrm{C}$ samples (Figure $2 \mathrm{~d}, \mathrm{e}, \mathrm{g}, \mathrm{h}$ ) evidenced the presence of remainder polymer into the nanotubes and their morphologies did not suffer the same changes as sample TDN_B600 (Figure 2f,i) (more SEM and TEM images of TDN_A, TDN_400B and TDN_600B can be found in Supplementary Information, Figure S2). From now on, samples TDN_B600 will be named TDN since it was the selected methodology to remove polymer. SEM analysis confirmed that TDN were hollow and their walls have some porosities (Figure 3a,b).
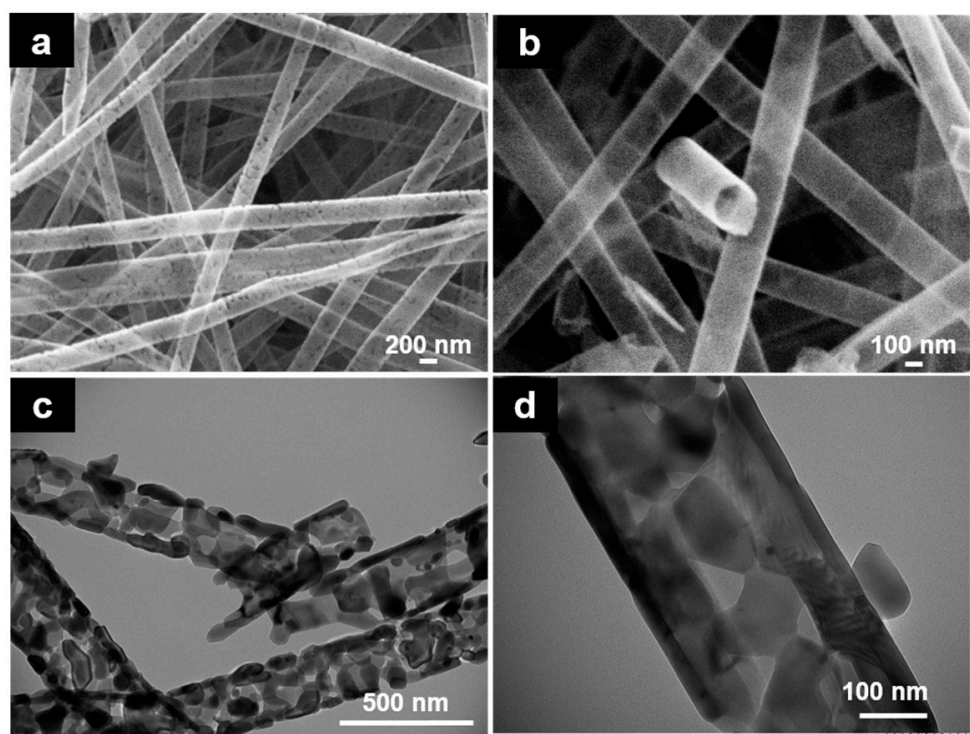

Figure 3. (a,b) SEM images of TDN_B600; (c,d) TEM images of TDN_B600 $(20,000 \times$ and 60,000×, respectively).

The release of compounds resulted from the PVN degradation, such as water and acetaldehyde byproducts, during aggressive thermal treatment process $\left(600^{\circ} \mathrm{C}\right)$, could have generated sufficient pressure into the nanotubes resulting in these fractures in the nanotube walls. Figure $3 c, d$ show the tubular structure of TDN was maintained with interconnected nanocrystal chains and their wall thicknesses were approximately 19-22 nm. Probably, these structures were produced by thermal exposure of titanium dioxide, which led to crystal phase change, from amorphous phase to anatase crystalline structure and to rutile at higher temperatures [23].

This small wall thickness is very interesting since other methods have resulted in nanoparticles with a larger particle size, such as the sol-gel method by Mosquera et al. that end up in particles with sizes between 114-171 nm [36]. Other works have shown higher metal oxide deposition rates, such as Park et al. studies where 500 cycles resulted in $80 \mathrm{~nm}$ zinc oxide depositions [37]. These results revealed that, in addition of temperature, the thickness of nanotubes resulting from ALD process is also clearly dependent on other factors, principally the substrate and the precursors used.

\subsection{Thermal Characterization of Nanofibers and Nanotubes}

TGA curves of mass loss with temperature of PVN, PVN_TiO 2 at different temperatures, TDN and commercial $\mathrm{TiO}_{2}$ NPs are presented in Figures 4 and 5. TGA curves of PV and PVN presented common PV degradation processes: (i) below $100{ }^{\circ} \mathrm{C}$, a $10 \%$ loss mass related with samples' dehydration; (ii) a process between $220^{\circ} \mathrm{C}$ and $390^{\circ} \mathrm{C}$ related to the separation of side groups which formed water, acetic acid and acetaldehyde byproducts and the loss of hydrogen bond between PV chains and O-bond 
between $\mathrm{C}-\mathrm{O}$; and (iii) a process between $390^{\circ} \mathrm{C}$ and $480{ }^{\circ} \mathrm{C}$ attributed to the degradation of principal chain of polymer [38,39]. In addition, PVN presented a maximum degradation temperature lower than PV polymer. This fact was already observed before and it is common in electrospun structures because a change occurred in the polymer structure to nanoscale during electrospinning process, increasing the specific surface and the heat penetrate faster [40].

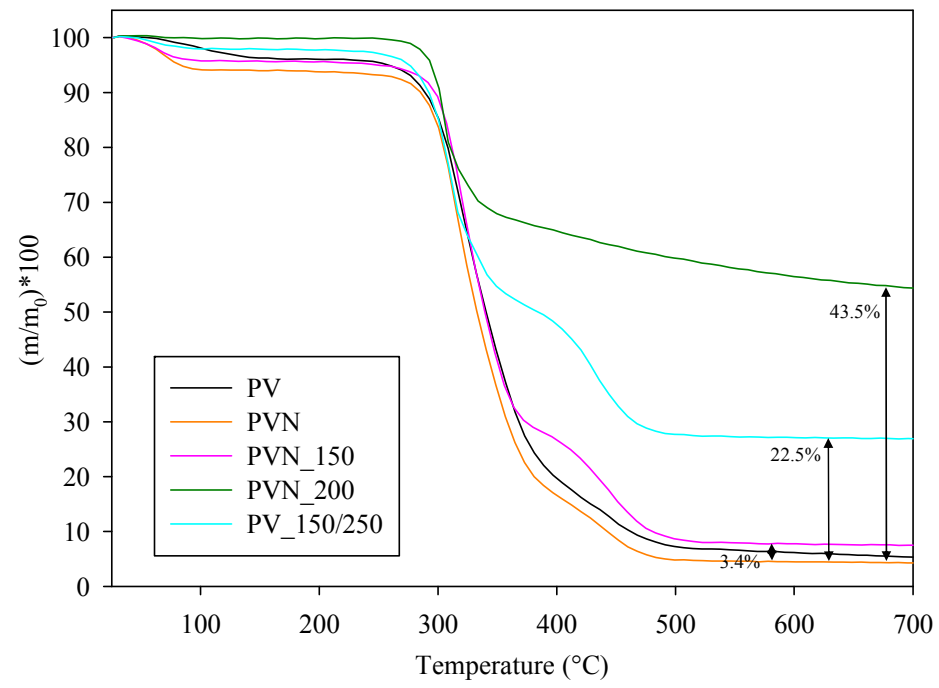

Figure 4. Weight loss with temperature of $\mathrm{PVOH}$ polymer (PV), electrospun nanofibers (PVN) and nanofibers coated at different temperatures with their corresponding $\% \mathrm{TiO}_{2}$ deposited.

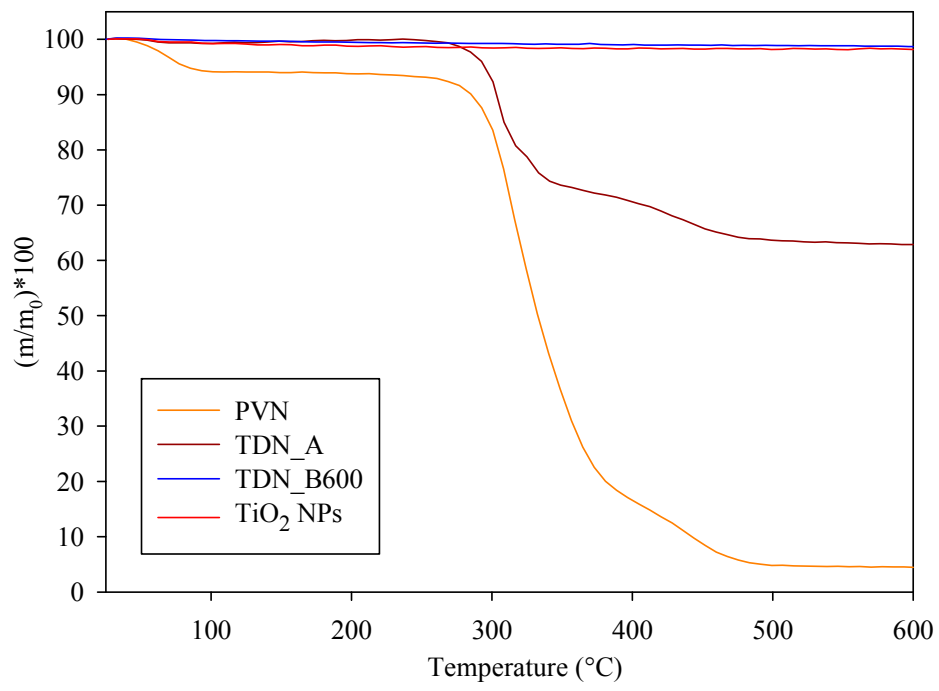

Figure 5. TGA curves of samples after polymer removal processes of TDN coated at $200^{\circ} \mathrm{C}$.

Since titanium dioxide does not undergo degradation with temperature, the most important information obtained from these analyses was the quantification of $\mathrm{TiO}_{2}$ deposited over the nanofibers, which are shown in Figure 4 and expressed in $\% \mathrm{TiO}_{2}$ respect total sample weight. ALD process at $150^{\circ} \mathrm{C}$ (PVN_150) resulted in a low deposition rate but when the temperature of chamber increased to $200{ }^{\circ} \mathrm{C}$ (sample PVN_200) the percentage of titanium dioxide deposited achieved the highest value of $43.5 \%$. Although other works have achieved high quality ALD depositions at low temperatures, ALD process parameters are highly dependent on ALD equipment. Some ALD processes have developed $\mathrm{TiO}_{2}$ thin films even at room temperature by using PE-ALD (ALD-enhanced plasma) or a home-made 
ALD with a very small camera $[25,41]$. On the other hand, Bishal et al. (2017) have recently evidenced that the deposition rate varied with gradually increasing temperature [25]. The third deposition (PVN_150/250) showed a titanium dioxide deposition value of $22.5 \%$. The first 250 cycles at $150{ }^{\circ} \mathrm{C}$ were carried out in order to protect PVN structures to perform as template for a further deposition at $250{ }^{\circ} \mathrm{C}$ in case PV could be degraded at this temperature. Certainly, this low temperature was not sufficient to achieve efficient deposition with our equipment. According to these results, the deposition at $200{ }^{\circ} \mathrm{C}$ was the process selected to obtain the samples for further analysis.

TGA analysis was also useful to confirm the effectiveness of PV removal processes. Figure 5 revealed calcination at $600{ }^{\circ} \mathrm{C}$ was the unique process to produce the total PV removal. In addition, TDN and $\mathrm{TiO}_{2}$ samples showed a weight loss between 1-2\%, which is related with the decomposition of same hydroxyls groups of titanium dioxide surface [42].

\subsection{X-ray Analysis Results}

XRD analyses of poly (vinyl alcohol) (PV), poly (vinyl alcohol) nanofibers (PVN) and deposited nanofibers at $200{ }^{\circ} \mathrm{C}$ by ALD (PVN_200) are plotted in Figure 6A. The PV diffraction pattern presented characteristic peaks at $2 \theta=11.2,19.5,22.1,32.1$ and $40.2^{\circ}$, which were attributed to semi-crystalline nature of polymer [43-45]. On the other hand, the diffraction patterns of PVN presented an amorphous aspect, exhibiting only one peak at $2 \theta=19.5^{\circ}$. Polymer crystallinity was highly affected by electrospinning process, where a fast speed of solvent evaporation led to a low molecular disposition $[39,40]$. The diffraction pattern of deposited PVN_200 presented some PV characteristic peaks at $2 \theta=9.9,19.9$ and $22.0^{\circ}$. Likewise, a displacement of peak at $11.2^{\circ}$ to $9.9^{\circ}$ was observed. This fact was due to the deposition of titanium dioxide over the PVN. During ALD process, the precursors were deposited in the surface of PVN causing their coating. The displacement of the peak can be caused due to the intercalations between the deposited $\mathrm{TiO}_{2}$ and the PV polymeric chains. In addition, as Figure 6A shows, the deposited titanium dioxide presented an amorphous phase, because $\mathrm{TiO}_{2}$ layers did not present crystalline structure [34].

Figure $6 \mathrm{~B}$ shows the effectiveness of the treatments to eliminate the polymer from nanotubes. $\mathrm{PV}$ residual in $\mathrm{TiO}_{2}$ nanotubes after washing and calcination at $400{ }^{\circ} \mathrm{C}$ was also confirmed by $\mathrm{XRD}$ analysis, showing an intense peak at $22.4^{\circ}$. In addition, the calcination at $400{ }^{\circ} \mathrm{C}$ showed other peak at $25.5^{\circ}$ associated to the anatase crystalline structure of titanium dioxide. On the contrary, the calcination at highest temperature $\left(600{ }^{\circ} \mathrm{C}\right)$ did not show any peak associated to PV polymer, only, a broad band between $15^{\circ}$ and $35^{\circ}$ was observed, which could be attributed to ash residues of polymer.

XRD diffraction patterns of commercial titanium dioxide $\left(\mathrm{TiO}_{2}\right)$ nanoparticles and hollow titanium dioxide nanotubes (TDN corresponding to TDN_B600) presented several peaks, as shown in Figure 6C. Both $\mathrm{TiO}_{2}$ nanostructures evidenced characteristics peaks of anatase crystalline structure $\mathrm{TiO}_{2}$ at $2 \theta=25.3,36.8,37.7,38.1,47.9,53.8,54.9,62.6,68.7,70.1$ and $74.9^{\circ}[23,46,47]$. In addition, peaks at $2 \theta=27.4,36.1$ and $56.2^{\circ}$ indicated that $\mathrm{TiO}_{2}$ also presented some nanoparticles with rutile crystalline structure $[48,49]$. Some studies have confirmed that anatase is a metastable structure which can be irreversibly transformed to an stable rutile structure between $400{ }^{\circ} \mathrm{C}$ and $1000{ }^{\circ} \mathrm{C}$, but, in general this fact will be dependent of nanocrystal size, deviations of stoichiometry, superficial area, microstructure of anatase powder and temperature of thermal treatment [50,51]. Fortunately, this conversion to rutile did not occur, since it is more interesting to maintain anatase crystallographic structure due to their higher antimicrobial activity [52]. Likewise, the sizes of commercial $\mathrm{TiO}_{2} \mathrm{NPs}$ and TDNs were calculated using Debye-Scherrer's equation. Results indicated crystallite size of TDN was $25 \mathrm{~nm}$ and commercial $\mathrm{TiO}_{2}$ nanoparticles presented crystallite size of $20 \mathrm{~nm}$, result that confirmed data sheet value. 


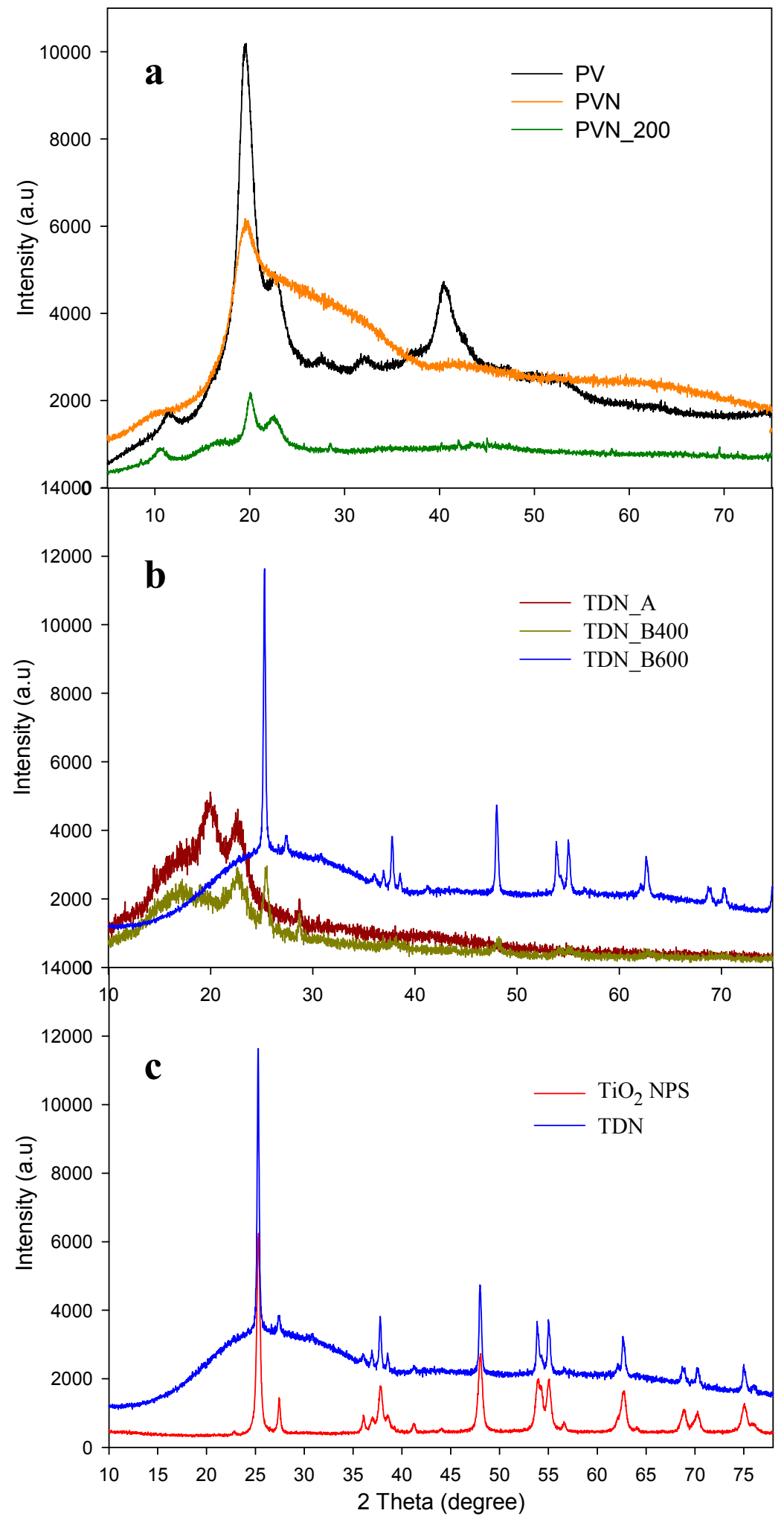

Figure 6. X-ray diffraction patterns of: (a) PV polymer and uncoated and coated through ALD PV electrospun nanofibers; (b) samples after removal polymer processes; and (c) commercial $\mathrm{TiO}_{2} \mathrm{NPs}$ and titanium dioxide nanotubes (TDN). 


\subsection{FTIR Analysis Results}

Figure 7 shows FTIR spectra recorded of PV polymer, PVN and titanium dioxide nanostructures and their characteristic peaks are presented in Table 1. Although PV and PVN clearly presented the main absorption bands of this polymer, PVN nanofibers did not show the presence of the peak associated to the crystal sequence related to $\mathrm{C}-\mathrm{O}$ stretching at $1143 \mathrm{~cm}^{-1}$ due to the reduction of crystallinity of the polymer caused by the electrospinning process, as it was already seen through DRX analysis $[44,53,54]$. This fact was also evidenced by a reduction of ratio $\left(D_{1145} / D_{1096}\right)$ which had been closely related to degree of crystallinity [55].

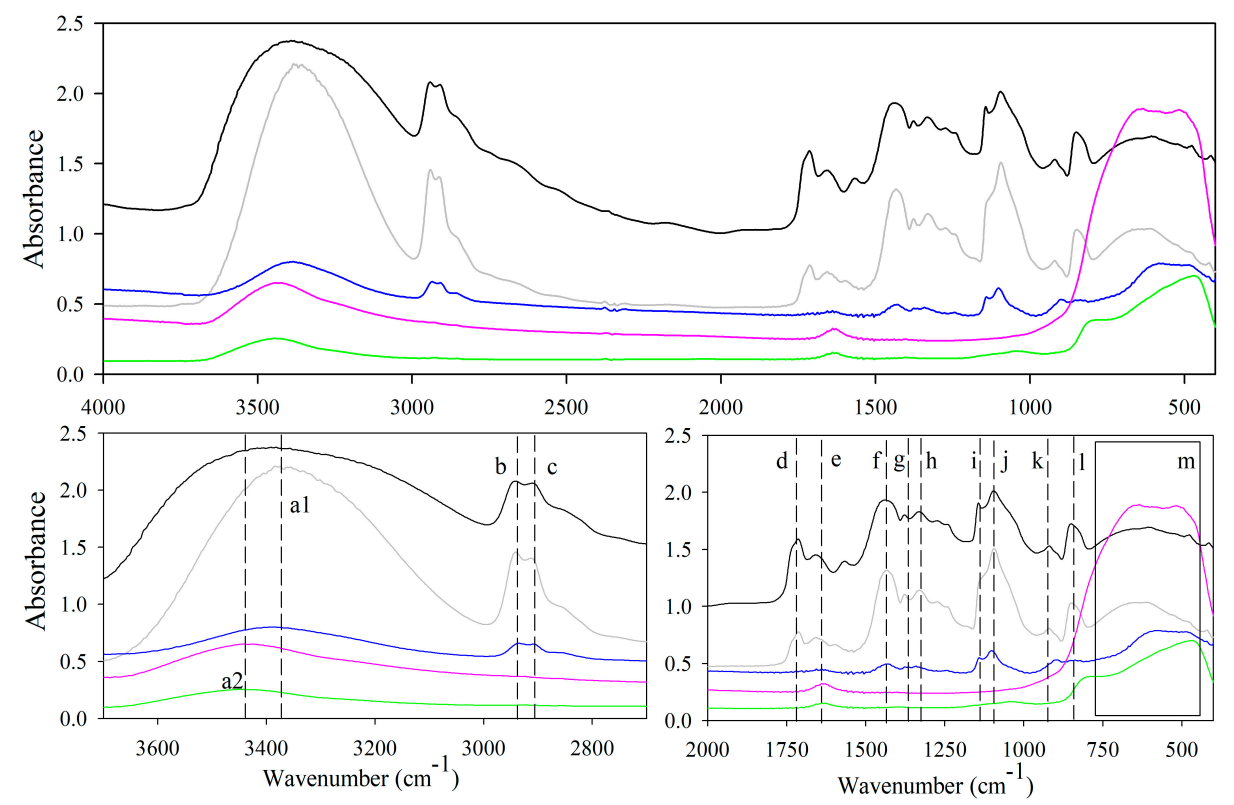

Figure 7. FTIR spectra of PV polymer (black), uncoated PVN (grey), ALD-coated PVN_200 (blue), commercial $\mathrm{TiO}_{2} \mathrm{NPs}$ (pink) and TDN (green) and letter a-l correspond to specific peaks from Table 2.

Table 1. Characteristic wavenumbers expressed in $\left(\mathrm{cm}^{-1}\right)$ associated to assignments of FTIR absorption bands of PV polymer, $\mathrm{PVN}$ and $\mathrm{TiO}_{2}$ nanostructures.

\begin{tabular}{cccccc}
\hline Peaks & PV Polymer & PVN & TiO $_{2}$ NPs & TDN & Assignment \\
\hline $\mathrm{a}$ & $3384(\mathrm{a} 1)$ & $3380(\mathrm{a} 1)$ & $3442(\mathrm{a} 2)$ & $3443(\mathrm{a} 2)$ & $\mathrm{O}-\mathrm{H}$ stretching \\
\hline $\mathrm{b}$ & 2942 & 2941 & - & - & $-\mathrm{CH}_{2}-$ stretching \\
\hline $\mathrm{c}$ & 2910 & 2913 & - & - & $-\mathrm{CH}_{2}-$ symmetrical and asymmetrical stretching \\
\hline $\mathrm{d}$ & 1715 & 1714 & - & - & $\mathrm{C}=\mathrm{O}, \mathrm{C}-\mathrm{O}$ band from carbonyl group \\
\hline $\mathrm{e}$ & - & - & 1637 & 1639 & bending modes of water Ti-OH \\
\hline $\mathrm{f}$ & 1435 & 1434 & - & - & $\mathrm{CH}_{2}, \mathrm{O}-\mathrm{H}$ and $\mathrm{C}-\mathrm{H}$ bending \\
\hline $\mathrm{g}$ & 1377 & 1377 & - & - & $\mathrm{CH}_{2}$ wagging \\
\hline $\mathrm{h}$ & 1333 & 1330 & - & - & $\mathrm{O}-\mathrm{H}$ in-plane bending with $\mathrm{C}-\mathrm{H}$ wagging \\
\hline $\mathrm{i}$ & 1143 & - & - & - & $\mathrm{C}-\mathrm{C}$ stretching, $\mathrm{O}-\mathrm{H}$ bending, $\mathrm{C}-\mathrm{O}-\mathrm{C}, \mathrm{C}-\mathrm{O}$ \\
\hline $\mathrm{j}$ & 1094 & 1094 & & - & $\mathrm{CO}$ stretching, OCC antisymmetric stretching \\
\hline $\mathrm{k}$ & 919 & 920 & - & - & $\mathrm{CH}_{2}$ bending \\
\hline l & 851 & 849 & - & $\mathrm{CH} \mathrm{H}_{2}$ rocking \\
\hline $\mathrm{m}$ & - & - & $700-400$ & $800-400$ & Ti-O-Ti bonding \\
\hline
\end{tabular}

FTIR spectra of commercial $\mathrm{TiO}_{2}$ NPs showed some characteristics peaks resulted from $\mathrm{O}-\mathrm{H}$ interaction in the $\mathrm{TiO}_{2}$ surface (peak a2 at $3442 \mathrm{~cm}^{-1}$ in Figure 7) and the scissors type deformation of adsorbed water protons (peak e at $1637 \mathrm{~cm}^{-1}$ ) [36,50,54]. Although characteristic peaks of Ti-O bonds 
for anatase and rutile phases have been specifically identified by El-Sherbiny et al., other studies have also registered a very broad band in a range of $400-700 \mathrm{~cm}^{-1}$ due to the vibration of Ti-O-Ti bonds in $\mathrm{TiO}_{2}$ lattice [23,56-59]. PVN_200 spectra easily revealed the residual PV through the presence of PVN characteristics, such as the presence of peaks at $2941 \mathrm{~cm}^{-1}, 2913 \mathrm{~cm}^{-1}$ and $1094 \mathrm{~cm}^{-1}$.

Additionally, a broad band appeared between 519 and $623 \mathrm{~cm}^{-1}$, which can be related to the stretching vibrations of Ti-O, Ti-O-C and Ti-O-Ti bonds [23,51]. Previous studies have confirmed bonding Ti-O-Ti bond appears when the TDMAT is introduced in the chamber and its molecules are chemisorbed by active sites of substrate surface, consuming - $\mathrm{OH}$ groups and producing reactive groups Ti- $\left(\mathrm{N}\left(\mathrm{CH}_{3}\right)_{2}\right)_{3}$, which are present in the subsurface of substrate. Immediately, the purge with $\mathrm{N}_{2}$ eliminates byproducts and remaining TDMAT and the ultrapure water is introduced in the chamber, the oxidation process continues and $\mathrm{Ti}-\mathrm{O}-\mathrm{Ti}$ bonding is formed. Finally, a film of $\mathrm{TiO}_{2}$ is formed over the surface of substrate, where the titanium atoms are connected by oxygen atoms [34,51]. FTIR spectra of TDN showed similar peaks to $\mathrm{TiO}_{2} \mathrm{NPs}$ associated to the stretching vibration of $\mathrm{OH}$ group $\left(3443 \mathrm{~cm}^{-1}\right)$, bending modes of water Ti-OH $\left(1639 \mathrm{~cm}^{-1}\right)$ and vibration of Ti-O-Ti bonds in the range between 400 and $800 \mathrm{~cm}^{-1}[23,58,60]$.

\subsection{Antimicrobial Activities Results}

Antimicrobial activities results are shown in Table 2 and were expressed as log reduction calculated following Equation (1). When exposed to UVA light, TDN presented interesting antimicrobial capacities and, as it was expected, the reduction in all bacterial concentrations increased as the concentration of titanium dioxide nanotubes increased. It is necessary to mention the effect of UVA irradiation on microorganisms was also checked and results verified that UVA irradiation inhibited bacteria negligibly, presenting only $0.1 \log$ cycles reduction. TDN concentrations between 150 and $400 \mu \mathrm{g} / \mathrm{mL}$ resulted in high and sometimes total inhibition of studied bacteria.

Table 2. Antimicrobial results of $\mathrm{TDN}$ and commercial $\mathrm{TiO}_{2} \mathrm{NPs}$ at different concentrations against different microorganisms.

\begin{tabular}{|c|c|c|c|c|c|c|}
\hline \multirow{2}{*}{$\begin{array}{c}\text { Microorganism: } \\
\text { TDN } \\
(\mu \mathrm{g} / \mathrm{mL})\end{array}$} & \multicolumn{2}{|c|}{ Escherichia coli } & \multicolumn{2}{|c|}{ Staphylococcus aureus } & \multicolumn{2}{|c|}{ Listeria innocua } \\
\hline & $\begin{array}{l}\text { Cel. conc. } \\
\text { (cfu/mL) }\end{array}$ & $\begin{array}{c}\text { Log } \\
\text { Reduction }\end{array}$ & $\begin{array}{l}\text { Cel. conc. } \\
\text { (cfu /mL) }\end{array}$ & $\begin{array}{c}\text { Log } \\
\text { Reduction }\end{array}$ & $\begin{array}{l}\text { Cel. conc. } \\
\text { (cfu/mL) }\end{array}$ & $\begin{array}{c}\text { Log } \\
\text { Reduction }\end{array}$ \\
\hline 0 & $(3.95 \pm 0.16) \times 10^{5}$ & $0^{\mathrm{a}}$ & $(2.02 \pm 0.12) \times 10^{5}$ & $0^{\mathrm{a}}$ & $(5.93 \pm 0.38) \times 10^{5}$ & $0^{\mathrm{a}}$ \\
\hline 100 & $(5.36 \pm 0.29) \times 10^{4}$ & $0.87 \pm 0.02^{b}$ & $(3.14 \pm 0.34) \times 10^{4}$ & $0.81 \pm 0.04^{b}$ & $(1.01 \pm 0.63) \times 10^{5}$ & $0.84 \pm 0.26^{b}$ \\
\hline 150 & $(8.67 \pm 0.47) \times 10^{2}$ & $2.66 \pm 0.03^{\mathrm{e}}$ & $(1.27 \pm 0.28) \times 10^{4}$ & $1.21 \pm 0.08^{\mathrm{c}}$ & $(4.46 \pm 0.25) \times 10^{4}$ & $1.12 \pm 0.02^{\mathrm{c}}$ \\
\hline 200 & 0 & $5.59 \mathrm{~g}$ & $(1.32 \pm 0.22) \times 10^{3}$ & $2.19 \pm 0.06^{\mathrm{d}}$ & $(4.20 \pm 0.27) \times 10^{4}$ & $1.15 \pm 0.02^{\mathrm{c}, \mathrm{d}}$ \\
\hline 400 & 0 & $5.59 \mathrm{~g}$ & $(5.33 \pm 0.23) \times 10^{2}$ & $2.58 \pm 0.02^{e}$ & $(5.05 \pm 0.07) \times 10^{3}$ & $2.07 \pm 0.01^{\mathrm{f}}$ \\
\hline $\begin{array}{l}\mathrm{TiO}_{2} \mathrm{NPs} \\
(\mu \mathrm{g} / \mathrm{mL})\end{array}$ & $\begin{array}{l}\text { Cel. conc. } \\
(\mathrm{cfu} / \mathrm{mL})\end{array}$ & $\begin{array}{c}\text { Log } \\
\text { Reduction }\end{array}$ & $\begin{array}{l}\text { Cel. conc. } \\
(\mathrm{cfu} / \mathrm{mL})\end{array}$ & $\begin{array}{c}\log \\
\text { Reduction }\end{array}$ & $\begin{array}{l}\text { Cel. conc. } \\
(\mathrm{cfu} / \mathrm{mL})\end{array}$ & $\begin{array}{c}\text { Log } \\
\text { Reduction }\end{array}$ \\
\hline 0 & $(4.58 \pm 1.52) \times 10^{5}$ & $0^{a}$ & $(1.98 \pm 0.29) \times 10^{5}$ & $0^{a}$ & $(3.57 \pm 0.48) \times 10^{5}$ & $0^{a}$ \\
\hline 100 & $(5.42 \pm 0.45) \times 10^{3}$ & $1.93 \pm 0.04^{\mathrm{c}}$ & $(2.75 \pm 0.19) \times 10^{2}$ & $2.86 \pm 0.02^{\mathrm{f}}$ & $(1.42 \pm 0.21) \times 10^{4}$ & $1.40 \pm 0.05^{\mathrm{e}}$ \\
\hline 150 & $(2.77 \pm 0.48) \times 10^{3}$ & $2.22 \pm 0.08^{d}$ & $(1.67 \pm 0.89) \times 10^{2}$ & $3.12 \pm 0.21^{g}$ & $(1.63 \pm 0.65) \times 10^{4}$ & $1.37 \pm 0.15^{\mathrm{d}, \mathrm{e}}$ \\
\hline 200 & $(5.17 \pm 0.88) \times 10^{2}$ & $2.95 \pm 0.07^{\mathrm{f}}$ & 0 & $5.36^{\mathrm{h}}$ & $(1.03 \pm 0.12) \times 10^{3}$ & $2.54 \pm 0.04^{g}$ \\
\hline 400 & 0 & $5.66^{\mathrm{g}}$ & 0 & $5.36^{\mathrm{h}}$ & $(7.17 \pm 0.95) \times 10^{2}$ & $2.69 \pm 0.05^{g}$ \\
\hline
\end{tabular}

When compared to other nanoparticles whose bactericidal properties were reported in previous works, TDN presented higher antibacterial capacities. Common nanoparticles concentrations used to inhibit Gram-positive and Gram-negative bacteria were markedly higher than TDN concentrations used in this work. Common applied dosages range of different nanoparticles, such as zinc oxide NPs, silver, nickel and copper oxide NPs were between 0.35 and $20 \mathrm{mg} / \mathrm{L}$ [61].

Due to the photocatalytic nature of titanium dioxide, one of the main mechanism of action of TDN is through the generation of reactive oxygen species (ROS) on its surface during the process of photocatalysis when they were exposed to light at an appropriate wavelength. The relationship 
between the absorption of energy by an electron to overcome from the valence gap to reach the conduction band, the generation of electron-hole pairs and the formation of different ROS and other radical species have been studied [62-64]. In addition, the destruction or damage of cell membrane as the main process for bacteria inactivation has been indirectly evidenced by studies of leakage of cellular components, such as potassium cations, RNA and protein $[65,66]$.

In this study, antimicrobial activities of commercial $\mathrm{TiO}_{2} \mathrm{NPs}$ were also evaluated in order to study the effect of morphology on antimicrobial ability (SEM image of $\mathrm{TiO}_{2}$ NPs can be found in Supplementary Information, Figure S3). As it can be observed in Table 2, both morphologies presented high antimicrobial activities but no trend was established since both nanostructures presented best performance against different microorganisms. TDN presented largest antimicrobial activity against Escherichia coli, presenting total bacteria reduction at $200 \mu \mathrm{g} / \mathrm{mL}$. Antimicrobial effectiveness is strongly influenced by interaction between antimicrobial agent and microorganisms. Certainly, hollow TDN morphologies allowed a greater contact area (external and internal) with this bacterial solution, allowing a greater ROS formation. Furthermore, bactericidal action of nanoparticles typically involves a combination of physical and chemical mechanisms and many factors, such as size, shape and the nature of the target microorganism, influence on their toxicological profile toward microorganisms. As it was already commented with other antimicrobial nanotube structures, the mechanism of toxicity can be also influenced by other factors such as diameter, length and surface chemistry that influence on diffusion of bacteria into these structures. Research developed by Upadhyayula et al. to determine adsorption kinetics of E. coli and S. aureus on single-walled carbon nanotubes have revealed diffusivity of bacterial cells are concentration and bacteria dependent $[67,68]$. As a result, TDN antimicrobial activity was even higher than commercial $\mathrm{TiO}_{2} \mathrm{NPs}$. On the other hand, TDN antimicrobial power was lower against Gram-positive bacteria. Several studies have shown that Gram-positive bacteria were more resistant to photocatalytic disinfection than Gram-negative bacteria [69,70]. The main difference between both bacteria is the cell wall structure. Gram-negative bacteria have a triple-layer cell with an inner membrane, a thin peptidoglycan layer and an outer membrane, while Gram-positive bacteria have a thicker peptidoglycan layer and no outer membrane. Certainly, the thicker peptidoglycan layer implied a higher protection for Gram-positive bacteria.

$\mathrm{TiO}_{2}$ NPs showed highest antimicrobial activity against S. aureus. Probably, their size and morphology allowed them to have a better affinity with this bacterial cell, which produced greater contact and therefore higher log reduction efficiency. Ultimately, in the case of L. innocua, both $\mathrm{TiO}_{2}$ nanostructures presented similar activities and lowest antimicrobial values when compared with other bacteria. This high resistance by Listeria genera was already observed in other works [71].

The above results confirmed that antimicrobial activities are highly influenced by several factors including the nanostructures morphology, source, size, concentration and microorganism $[9,10,13,72]$. The control of morphology and nanostructure of $\mathrm{TiO}_{2}$ is an important factor to enhance its antimicrobial activity. In general, the appropriate design based on desirable surface properties given by shaped nanoparticles is dependent of type of bacteria. Other studies have already claimed the shape of the nanoparticles is one of the most important properties which affects their physico-chemical properties [73].

\section{Conclusions}

In summary, this research has shown the combination of electrospinning and atomic layer deposition techniques as an attractive way to obtain novel metal oxide nanostructures with promising antimicrobial purposes. Titanium dioxide nanotubes were satisfactorily developed through atomic layer deposition of tetrakis (dimethylamide) titanium (TDMAT) and ultra-pure water, as precursors, over polyvinyl alcohol electrospun nanofibers. Thermal and structural properties studied through thermogravimetric, XRD, FTIR, SEM and TEM analysis were of great importance to understand the process during all stages. The highest $\mathrm{TiO}_{2}$ deposition efficiency was achieved with an ALD temperature chamber of $200{ }^{\circ} \mathrm{C}$ and thermal treatment of deposited samples at $600{ }^{\circ} \mathrm{C}$ was the 
most efficient process to remove PV polymer in order to obtain hollow $\mathrm{TiO}_{2}$ nanotubes (TDN). The specific mechanisms that govern the antimicrobial activities of TDN was not studied in this research and, as with other nanoparticles, it is hugely challenging to understand individual and synergistic contributions of physical, chemical and electrical effects of nanoparticles on cells. Antimicrobial analysis revealed TDN showed higher bactericidal power against Escherichia coli than commercial $\mathrm{TiO}_{2}$ nanoparticles but lower activity in the case of Staphylococcus aureus. Results evidenced bactericidal activities are highly dependent of many factors, including intrinsic properties of nanomaterials and bacteria type.

Supplementary Materials: The following are available online at www.mdpi.com/2079-4991/8/2/128/s1. Contents: Section S1.1. Study of the effect of electrospinning parameters on fiber diameter; Section S1.2. Provider's recipe Cambridge Nanotech; Section S2.1. Morphological results of nanofiber; Section S2.2. Morphological results of $\mathrm{TiO}_{2}$ nanostructures.

Acknowledgments: The authors acknowledge the Financial support of CONICYT through the Project Fondecyt Regular 1170624, "Programa de Financiamiento Basal para Centros Científicos y Tecnológicos de Excelencia" (Project FB0807) and Fondequip EQM120045.

Author Contributions: Cristian Patiño worked on electrospinning and calcination processes to obtain homogeneous electrospun fibers and hollow nanotubes, respectively, and performed characterization measurements. Daniela Alburquenque performed atomic layer depositions supervised by Juan Escrig. Juan Luis Palma characterized nanostructures through SEM and TEM microscopies. Carol Lopez de Dicastillo proposed and planned the research. Maria Jose Galotto guided the execution of antimicrobial measurements. Cristian Patiño and Carol Lopez de Dicastillo elaborated the writing.

Conflicts of Interest: The authors declare no conflicts of interest.

\section{References}

1. Colavecchio, A.; Cadieux, B.; Lo, A.; Goodridge, L.D. Bacteriophages Contribute to the Spread of Antibiotic Resistance Genes among Foodborne Pathogens of the Enterobacteriaceae Family-A Review. Front. Microbiol. 2017, 8, 1108. [CrossRef] [PubMed]

2. Shamsizadeh, Z.; Nikaeen, M.; Nasr Esfahani, B.; Mirhoseini, S.H.; Hatamzadeh, M.; Hassanzadeh, A. Detection of antibiotic resistant Acinetobacter baumannii in various hospital environments: Potential sources for transmission of Acinetobacter infections. Environ. Health Prev. Med. 2017, 22, 44. [CrossRef] [PubMed]

3. Wang, L.; Hu, C.; Shao, L. The antimicrobial activity of nanoparticles: Present situation and prospects for the future. Int. J. Nanomed. 2017, 12, 1227-1249. [CrossRef] [PubMed]

4. Zhang, M.; Zhao, Y.; Yan, L.; Peltier, R.; Hui, W.; Yao, X.; Cui, Y.; Chen, X.; Sun, H.; Wang, Z. Interfacial Engineering of Bimetallic Ag/Pt Nanoparticles on Reduced Graphene Oxide Matrix for Enhanced Antimicrobial Activity. ACS Appl. Mater. Interfaces 2016, 8, 8834-8840. [CrossRef] [PubMed]

5. Rai, M.K.; Deshmukh, S.D.; Ingle, A.P.; Gade, A.K. Silver nanoparticles: The powerful nanoweapon against multidrug-resistant bacteria. J. Appl. Microbiol. 2012, 112, 841-852. [CrossRef] [PubMed]

6. Sui, M.; Zhang, L.; Sheng, L.; Huang, S.; She, L. Synthesis of ZnO coated multi-walled carbon nanotubes and their antibacterial activities. Sci. Total Environ. 2013, 452-453, 148-154. [CrossRef] [PubMed]

7. Yah, C.S.; Simate, G.S. Nanoparticles as potential new generation broad spectrum antimicrobial agents. Daru 2015, 23, 43. [CrossRef] [PubMed]

8. Zhang, X.-F.; Liu, Z.-G.; Shen, W.; Gurunathan, S. Silver Nanoparticles: Synthesis, Characterization, Properties, Applications, and Therapeutic Approaches. Int. J. Mol. Sci. 2016, 17, 1534. [CrossRef] [PubMed]

9. De Oliveira, R.C.; de Foggi, C.C.; Teixeira, M.M.; Da Silva, M.D.P.; Assis, M.; Francisco, E.M.; Pimentel, B.N.; Pereira, P.F.; Vergani, C.E.; Machado, A.L.; et al. Mechanism of Antibacterial Activity via Morphology Change of $\alpha$-AgVO3: Theoretical and Experimental Insights. ACS Appl. Mater. Interfaces 2017, 9, 11472-11481. [CrossRef] [PubMed]

10. Pal, S.; Tak, Y.K.; Song, J.M. Does the antibacterial activity of silver nanoparticles depend on the shape of the nanoparticle? A study of the Gram-negative bacterium Escherichia coli. Appl. Environ. Microbiol. 2007, 73, 1712-1720. [CrossRef] [PubMed] 
11. Panáček, A.; Kvítek, L.; Prucek, R.; Kolář, M.; Večeřová, R.; Pizúrová, N.; Sharma, V.K.; Nevěčná, T.; Radek, Z. Silver Colloid Nanoparticles: Synthesis, Characterization, and Their Antibacterial Activity. J. Phys. Chem. B 2006, 110, 16248-16253. [CrossRef] [PubMed]

12. Galdiero, S.; Falanga, A.; Vitiello, M.; Cantisani, M.; Marra, V.; Galdiero, M. Silver Nanoparticles as Potential Antiviral Agents. Molecules 2011, 16, 8894-8918. [CrossRef] [PubMed]

13. Raza, M.A.; Kanwal, Z.; Rauf, A.; Sabri, A.N.; Riaz, S.; Naseem, S. Size- and Shape-Dependent Antibacterial Studies of Silver Nanoparticles Synthesized by Wet Chemical Routes. Nanomaterials 2016, 6, 74. [CrossRef] [PubMed]

14. Tamayo, L.A.; Zapata, P.A.; Vejar, N.D.; Azócar, M.I.; Gulppi, M.A.; Zhou, X.; Thompson, G.E.; Rabagliati, F.M.; Páez, M.A. Release of silver and copper nanoparticles from polyethylene nanocomposites and their penetration into Listeria monocytogenes. Mater. Sci. Eng. C Mater. Biol. Appl. 2014, 40, $24-31$. [CrossRef] [PubMed]

15. Wu, D.; Fan, W.; Kishen, A.; Gutmann, J.L.; Fan, B. Evaluation of the Antibacterial Efficacy of Silver Nanoparticles against Enterococcus faecalis Biofilm. J. Endod. 2014, 40, 285-290. [CrossRef] [PubMed]

16. Agarwal, S.; Greiner, A.; Wendorff, J.H. Functional materials by electrospinning of polymers. Prog. Polym. Sci. 2013, 38, 963-991. [CrossRef]

17. Li, X.; Li, Z.; Wang, L.; Ma, G.; Meng, F.; Pritchard, R.H.; Gill, E.L.; Liu, Y.; Huang, Y.Y.S. Low-Voltage Continuous Electrospinning Patterning. ACS Appl. Mater. Interfaces 2016, 8, 32120-32131. [CrossRef] [PubMed]

18. Marichy, C.; Bechelany, M.; Pinna, N. Atomic Layer Deposition of Nanostructured Materials for Energy and Environmental Applications. Adv. Mater. 2012, 24, 1017-1032. [CrossRef] [PubMed]

19. Nielsch, K.; Bachmann, J.; Daub, M.; Jing, J.; Knez, M.; Gösele, U.; Barth, S.; Mathur, S.; Escrig, J.; Altbir, D. Ferromagnetic Nanostructures by Atomic Layer Deposition: From Thin Films Towards Core-Shell Nanotubes. In ECS Transactions; ECS: Wollerau, Switzerland, 2007; Volume 11, pp. 139-148.

20. Haider, A.; Ozgit-Akgun, C.; Kayaci, F.; Okyay, A.K.; Uyar, T.; Biyikli, N. Fabrication of AlN/BN bishell hollow nanofibers by electrospinning and atomic layer deposition. APL Mater. 2014, 2, 96109. [CrossRef]

21. Heikkilä, P.; Hirvikorpi, T.; Hilden, H.; Sievänen, J.; Hyvärinen, L.; Harlin, A.; Vähä-Nissi, M. High surface area nanostructured tubes prepared by dissolution of ALD-coated electrospun fibers. J. Mater. Sci. 2012, 47, 3607-3612. [CrossRef]

22. Peng, Q.; Sun, X.-Y.; Spagnola, J.C.; Hyde, G.K.; Spontak, R.J.; Parsons, G.N. Atomic Layer Deposition on Electrospun Polymer Fibers as a Direct Route to $\mathrm{Al}_{2} \mathrm{O}_{3}$ Microtubes with Precise Wall Thickness Control. Nano Lett. 2007, 7, 719-722. [CrossRef] [PubMed]

23. Borbón-Nuñez, H.A.; Dominguez, D.; Muñoz-Muñoz, F.; Lopez, J.; Romo-Herrera, J.; Soto, G.; Tiznado, H. Fabrication of hollow $\mathrm{TiO}_{2}$ nanotubes through atomic layer deposition and MWCNT templates. Powder Technol. 2017, 308, 249-257. [CrossRef]

24. Santala, E.; Kemell, M.; Leskelä, M.; Ritala, M. The preparation of reusable magnetic and photocatalytic composite nanofibers by electrospinning and atomic layer deposition. Nanotechnology 2009, 20, 35602. [CrossRef] [PubMed]

25. Bishal, A.K.; Sukotjo, C.; Takoudis, C.G. Room temperature $\mathrm{TiO}_{2}$ atomic layer deposition on collagen membrane from a titanium alkylamide precursor. J. Vac. Sci. Technol. A Vacuum Surf. Films 2017, 35, 01B134. [CrossRef]

26. Ghosh, S.; Das, A.P. Modified titanium oxide $\left(\mathrm{TiO}_{2}\right)$ nanocomposites and its array of applications: A review. Toxicol. Environ. Chem. 2015, 97, 491-514. [CrossRef]

27. Ma, W.; Li, J.; Liu, Y.; Ren, X.; Gu, Z.-G.; Xie, Z.; Liang, J. Preparation and characterization of excellent antibacterial $\mathrm{TiO}_{2} / \mathrm{N}$-halamines nanoparticles. Colloids Surf. A Physicochem. Eng. Asp. 2016, 506, 284-290. [CrossRef]

28. Dudefoi, W.; Moniz, K.; Allen-Vercoe, E.; Ropers, M.-H.; Walker, V.K. Impact of food grade and nano-TiO 2 particles on a human intestinal community. Food Chem. Toxicol. 2017, 106, 242-249. [CrossRef] [PubMed]

29. Ramesh, T.; Nayak, B.; Amirbahman, A.; Tripp, C.P.; Mukhopadhyay, S. Application of ultraviolet light assisted titanium dioxide photocatalysis for food safety: A review. Innov. Food Sci. Emerg. Technol. 2016, 38, 105-115. [CrossRef]

30. Raut, A.V.; Yadav, H.M.; Gnanamani, A.; Pushpavanam, S.; Pawar, S.H. Synthesis and characterization of chitosan- $\mathrm{TiO}_{2}: \mathrm{Cu}$ nanocomposite and their enhanced antimicrobial activity with visible light. Colloids Surf. B Biointerfaces 2016, 148, 566-575. [CrossRef] [PubMed]

31. Jiang, X.; Lv, B.; Wang, Y.; Shen, Q.; Wang, X. Bactericidal mechanisms and effector targets of $\mathrm{TiO}_{2}$ and $\mathrm{Ag}-\mathrm{TiO}_{2}$ against Staphylococcus aureus. J. Med. Microbiol. 2017. [CrossRef] [PubMed] 
32. Podporska-Carroll, J.; Panaitescu, E.; Quilty, B.; Wang, L.; Menon, L.; Pillai, S.C. Antimicrobial properties of highly efficient photocatalytic $\mathrm{TiO}_{2}$ nanotubes. Appl. Catal. B Environ. 2015, 176-177, 70-75. [CrossRef]

33. Abendroth, B.; Moebus, T.; Rentrop, S.; Strohmeyer, R.; Vinnichenko, M.; Weling, T.; Stöcker, H.; Meyer, D.C. Atomic layer deposition of $\mathrm{TiO}_{2}$ from tetrakis(dimethylamino)titanium and $\mathrm{H}_{2} \mathrm{O}$. Thin Solid Films 2013, 545, 176-182. [CrossRef]

34. Edy, R.; Zhao, Y.; Huang, G.; Shi, J.; Zhang, J.; Solovev, A.A.; Mei, Y. TiO 2 nanosheets synthesized by atomic layer deposition for photocatalysis. Prog. Nat. Sci. Mater. Int. 2016, 26, 493-497. [CrossRef]

35. Takigawa, T.; Kasihara, H.; Masuda, T. Swelling and mechanical properties of polyvinylalcohol hydrogels. Polym. Bull. 1990, 24, 613-618. [CrossRef]

36. Mosquera, E.; Rosas, N.; Debut, A.; Guerrero, V.H. Síntesis y Caracterización de Nanopartículas de Dióxido de Titanio Obtenidas por el Método de Sol-Gel. Revista Politécnic 2015, 36, 5.

37. Park, J.Y.; Choi, S.-W.; Kim, S.S. A synthesis and sensing application of hollow ZnO nanofibers with uniform wall thicknesses grown using polymer templates. Nanotechnology 2010, 21, 475601. [CrossRef] [PubMed]

38. Shooto, N.D.; Dikio, C.W.; Wankasi, D.; Sikhwivhilu, L.M.; Mtunzi, F.M.; Dikio, E.D. Novel PVA/MOF Nanofibres: Fabrication, Evaluation and Adsorption of Lead Ions from Aqueous Solution. Nanoscale Res. Lett. 2016, 11, 414. [CrossRef] [PubMed]

39. López de Dicastillo, C.; Garrido, L.; Alvarado, N.; Romero, J.; Palma, J.; Galotto, M. Improvement of Polylactide Properties through Cellulose Nanocrystals Embedded in Poly(Vinyl Alcohol) Electrospun Nanofibers. Nanomaterials 2017, 7, 106. [CrossRef] [PubMed]

40. López de Dicastillo, C.; Roa, K.; Garrido, L.; Pereira, A.; Galotto, M. Novel Polyvinyl Alcohol/Starch Electrospun Fibers as a Strategy to Disperse Cellulose Nanocrystals into Poly(lactic acid). Polymers 2017, 9, 117. [CrossRef]

41. Nam, T.; Kim, J.-M.; Kim, M.-K.; Kim, H.; Kim, W.-H. Low-temperature Atomic Layer Deposition of $\mathrm{TiO}_{2}$, $\mathrm{Al}_{2} \mathrm{O}_{3}$, and $\mathrm{ZnO}$ Thin Films. J. Korean Phys. Soc. 2011, 59, 452-457. [CrossRef]

42. Xiao, Z.; Guo, P.; Sun, N. Preparation, thermostability, and hydrophobic properties of $\mathrm{TiO}_{2}$ /poly(dodecafluoroheptyl methacrylate) nanocomposites. J. Appl. Polym. Sci. 2017, 134. [CrossRef]

43. Mallakpour, S.; Sadeghzadeh, R. Surface modification of alumina with biosafe molecules: Nanostructure, thermal, and mechanical properties of PVA nanocomposites. J. Appl. Polym. Sci. 2017, 134. [CrossRef]

44. Su, L.; Fang, G. Characterization of Cross-linked Alkaline Lignin/Poly(Vinyl Alcohol) Film with a Formaldehyde Cross-linker. BioResources 2014, 9, 4477-4488. [CrossRef]

45. Guerrini, L.M.; de Oliveira, M.P.; Branciforti, M.C.; Custódio, T.A.; Bretas, R.E.S. Thermal and structural characterization of nanofibers of poly(vinyl alcohol) produced by electrospinning. J. Appl. Polym. Sci. 2009, 112, 1680-1687. [CrossRef]

46. He, Z.; Cai, Q.; Fang, H.; Situ, G.; Qiu, J.; Song, S.; Chen, J. Photocatalytic activity of $\mathrm{TiO}_{2}$ containing anatase nanoparticles and rutile nanoflower structure consisting of nanorods. J. Environ. Sci. 2013, 25, 2460-2468. [CrossRef]

47. Xie, Y.; Heo, S.; Yoo, S.; Ali, G.; Cho, S. Synthesis and Photocatalytic Activity of Anatase $\mathrm{TiO}_{2}$ Nanoparticles-coated Carbon Nanotubes. Nanoscale Res. Lett. 2009, 5, 603-607. [CrossRef] [PubMed]

48. Shi, Y.; Yang, Y.; Dong, G.; Jiang, Y.; Wei, L.; Su, T.; Fan, R. Three-dimensional flower-like rutile $\mathrm{TiO}_{2}$ microsphere composed of nanorods: A potential material as light scattering layer for DSSCs. Chem. Res. Chin. Univ. 2017, 33, 298-304. [CrossRef]

49. Wang, J.; Wang, H.; Yu, J. Synthesis of 1-D porous $\mathrm{TiO}_{2}$ on fly ash carriers through surface modification method. J. Phys. Chem. Solids 2017, 107, 7-13. [CrossRef]

50. Mendoza-Anaya; Salas, P.; Angeles-Chávez, C.; Pérez-Hernández, R.; Castaño, V.M. Caracterización microestructural y morfología de $\mathrm{TiO}_{2}$ para aplicaciones termoluminiscentes. Rev. Mex. Física 2003, 50, 12-16.

51. Zhuiykov, S.; Akbari, M.K.; Hai, Z.; Xue, C.; Xu, H.; Hyde, L. Wafer-scale fabrication of conformal atomic-layered $\mathrm{TiO}_{2}$ by atomic layer deposition using tetrakis (dimethylamino) titanium and $\mathrm{H}_{2} \mathrm{O}$ precursors. Mater. Des. 2017, 120, 99-108. [CrossRef]

52. Fu, G.; Vary, P.S.; Lin, C.-T. Anatase $\mathrm{TiO}_{2}$ Nanocomposites for Antimicrobial Coatings. J. Phys. Chem. B 2005, 109, 8889-8898. [CrossRef] [PubMed]

53. Rezaee, O.; Mahmoudi Chenari, H.; Ghodsi, F.E.; Ziyadi, H. Preparation of PVA nanofibers containing tungsten oxide nanoparticle by electrospinning and consideration of their structural properties and photocatalytic activity. J. Alloys Compd. 2017, 690, 864-872. [CrossRef] 
54. Enayati, M.S.; Behzad, T.; Sajkiewicz, P.; Bagheri, R.; Ghasemi-Mobarakeh, L.; Kuśnieruk, S.; Rogowska-Tylman, J.; Pahlevanneshan, Z.; Choińska, E.; Święszkowski, W. Fabrication and characterization of electrospun bionanocomposites of poly(vinyl alcohol)/nanohydroxyapatite/cellulose nanofibers. Int. J. Polym. Mater. Polym. Biomater. 2016, 65, 660-674. [CrossRef]

55. Sugiura, K.; Hashimoto, M.; Matsuzawa, S.; Yamaura, K. Influence of degree of crystallinity and syndiotacticity on infrared spectra of solid PVA. J. Appl. Polym. Sci. 2001, 82, 1291-1298. [CrossRef]

56. Vargas, A.; Ochoa, Y.; Ortegón, Y.; Mosquera, P.; Rodríguez, J.; Amado, R. Nanopartículas de Tio ${ }_{2}$, fase anatasa, sintetizadas por métodos químicos Nanoparticles of $\mathrm{TiO}_{2}$, anatase phase, synthesized by chemical methods. Ing. Desarro. Univ. Norte 2011, 29, 186-201.

57. Li, X.; Wang, D.; Luo, Q.; An, J.; Wang, Y.; Cheng, G. Surface modification of titanium dioxide nanoparticles by polyaniline via an in situ method. J. Chem. Technol. Biotechnol. 2008, 83, 1558-1564. [CrossRef]

58. Pan, H.; Wang, X.; Xiao, S.; Yu, L.; Zhang, Z. Preparation and characterization of $\mathrm{TiO}_{2}$ nanoparticles surface-modified by octadecyltrimethoxysilane. Indian J. Eng. Mater. Sci. 2013, 20, 561-567.

59. El-Sherbiny, S.; Morsy, F.; Samir, M.; Fouad, O.A. Synthesis, characterization and application of $\mathrm{TiO}_{2}$ nanopowders as special paper coating pigment. Appl. Nanosci. 2014, 4, 305-313. [CrossRef]

60. León, A.; Reuquen, P.; Garín, C.; Segura, R.; Vargas, P.; Zapata, P.; Orihuela, P. FTIR and Raman Characterization of $\mathrm{TiO}_{2}$ Nanoparticles Coated with Polyethylene Glycol as Carrier for 2-Methoxyestradiol—Semantic Scholar. Appl. Sci. 2017, 7, 49. [CrossRef]

61. Hajipour, M.J.; Fromm, K.M.; Ashkarran, A.; Jimenez de Aberasturi, D.; Ruiz de Larramendi, I.; Rojo, T.; Serpooshan, V.; Parak, W.J.; Mahmoudi, M. Antibacterial properties of nanoparticles. Trends Biotechnol. 2012, 30, 499-511. [CrossRef] [PubMed]

62. Dalrymple, O.K.; Stefanakos, E.; Trotz, M.A.; Goswamia, D.Y. A review of the mechanisms and modeling of photocatalytic disinfection. Appl. Catal. B Environ. 2010, 98, 27-38. [CrossRef]

63. Dutta, P.K.; Pehkonen, S.O.; Sharma, V.K.; Ray, A.K. Photocatalytic Oxidation of Arsenic(III): Evidence of Hydroxyl Radicals. Environ. Sci. Technol. 2005, 39, 1827-1834. [CrossRef] [PubMed]

64. Wong, C.C.; Chu, W. The Hydrogen Peroxide-Assisted Photocatalytic Degradation of Alachlor in $\mathrm{TiO}_{2}$ Suspensions. Environ. Sci. Technol. 2003, 37, 2310-2316. [CrossRef] [PubMed]

65. Kambala, V.S.R.; Naidu, R. Disinfection studies on $\mathrm{TiO}_{2}$ thin films prepared by a sol-gel method. J. Biomed. Nanotechnol. 2009, 5, 121-129. [CrossRef] [PubMed]

66. Gogniat, G.; Dukan, $\mathrm{S}$. $\mathrm{TiO}_{2}$ photocatalysis causes DNA damage via fenton reaction-generated hydroxyl radicals during the recovery period. Appl. Environ. Microbiol. 2007, 73, 7740-7743. [CrossRef] [PubMed]

67. Al-Jumaili, A.; Alancherry, S.; Bazaka, K.; Jacob, M.V. Review on the Antimicrobial Properties of Carbon Nanostructures. Materials 2017, 10, 1066. [CrossRef] [PubMed]

68. Upadhyayula, V.K.K.; Deng, S.; Mitchell, M.C.; Nair, V.K.; Smith, G.B.; Ghoshroy, S. Adsorption kinetics of Escherichia coli and Staphylococcus aureus on single-walled carbon nanotube aggregates. Water Sci. Technol. 2008, 58, 179-184. [CrossRef] [PubMed]

69. Foster, H.A.; Ditta, I.B.; Varghese, S.; Steele, A. Photocatalytic disinfection using titanium dioxide: Spectrum and mechanism of antimicrobial activity. Appl. Microbiol. Biotechnol. 2011, 90, 1847-1868. [CrossRef] [PubMed]

70. Erkan, A.; Bakir, U.; Karakas, G. Photocatalytic microbial inactivation over Pd doped $\mathrm{SnO}_{2}$ and $\mathrm{TiO}_{2}$ thin films. J. Photochem. Photobiol. A Chem. 2006, 184, 313-321. [CrossRef]

71. Ruiz Bolivar, Z.; Poutou Piñales, R.A.; Carrascal Camacho, A.K. Resistencia Antimicrobiana y a Desinfectantes de Spp. Nova 2008, 6, 201. [CrossRef]

72. Gilbertson, L.M.; Albalghiti, E.M.; Fishman, Z.S.; Perreault, F.; Corredor, C.; Posner, J.D.; Elimelech, M.; Pfefferle, L.D.; Zimmerman, J.B. Shape-Dependent Surface Reactivity and Antimicrobial Activity of Nano-Cupric Oxide. Environ. Sci. Technol. 2016, 50, 3975-3984. [CrossRef] [PubMed]

73. Burda, C.; Chen, X.; Narayanan, R.; El-Sayed, M.A. Chemistry and properties of nanocrystals of different shapes. Chem. Rev. 2005, 105, 1025-1102. [CrossRef] [PubMed]

(C) 2018 by the authors. Licensee MDPI, Basel, Switzerland. This article is an open access article distributed under the terms and conditions of the Creative Commons Attribution (CC BY) license (http:// creativecommons.org/licenses/by/4.0/). 